\title{
INTRAVAGINAL INOCULATION OF THE GUINEA-PIG WITH VIBRIO FETUS VAR. VENEREALIS DURING NATURAL AND INDUCED REPRODUCTIVE CYCLE PHASES*
}

\author{
A. F. WALSH, $\uparrow$ F. H. WHITE AND A. C. WARNICK \\ University of Florida, Veterinary Science and Animal Science, IFAS, \\ Gainesville, Florida 32611, U.S.A.
}

(Received 18th September 1973)

\begin{abstract}
Summary. Trials were conducted in which virgin female guinea-pigs were inoculated intravaginally with Vibrio fetus var. venerealis during the follicular and luteal phases of the reproductive cycle, during induced and natural oestrus and following the intramuscular injection of progesterone. In all trials, the results gave evidence of transitory infection, but failed to indicate any gross or microscopic changes in the reproductive system attributable to $V$. fetus var. venerealis infection.
\end{abstract}

\section{INTRODUCTION}

Smith (1918) reported the guinea-pig to be refractory to Vibrio fetus infection, and later (Smith, 1919) extended this view to include most small animal species used in laboratory studies. When the intraperitoneal route of inoculation was used, however, Smith (1923) was successful in infecting two out of three female guinea-pigs.

Ristic \& Morse (1953) inoculated pregnant guinea-pigs by various routes, with a mixed culture of ovine and bovine isolants of $V$. fetus, and reported infection in one guinea-pig inoculated intraperitoneally. Adler (1953) inoculated oestrogen-primed non-pregnant guinea-pigs with pure cultures of $V$. fetus by the vaginal route. The same author (Adler, 1953) included animals inoculated intravaginally with infected bull semen. A $50 \%$ infection rate was recorded in the test animals. A report by Power (1954) indicated almost identical results.

In the present study, attempts were made to establish infection with $V$. fetus var. venerealis (as defined by Florent, 1963) in the non-pregnant guinea-pig by inoculation into the vagina. The experimental conditions were varied so that infection was attempted during (1) the follicular and luteal phases of the reproductive cycle, (2) induced and natural oestrus and, (3) after the administration of exogenous progesterone.

* Published as paper No. 5047 in the Florida Agricultural Experiment Stations Journal Series.

+ Present address: Department of Microbiology, Orange Memorial Hospital, Orlando, Florida 32806, U.S.A. 


\section{MATERIALS AND METHODS}

\section{Vibrio isolant}

The organism used was a fresh smooth isolant of $V$. fetus var. venerealis previously identified by the criteria of Florent (1963). To avoid repeated subculture, stock cultures of the isolant were grown in Brucella broth (Albimi) for 24 to $48 \mathrm{hr}$ at $35^{\circ} \mathrm{C}$ and stored at $-70^{\circ} \mathrm{C}$. The techniques of isolation and propagation were those of Lovell (1964), and the gas mixture used for the growth of the isolants was that of Lovell (1964) as modified by Walsh \& White (1968).

\section{Experimental animals}

Mature virgin female guinea-pigs of 450 to $500 \mathrm{~g}$ weight were used. The animals were of the mixed and English short hair varieties. Each guinea-pig was housed separately in quarters maintained at $68 \pm 5^{\circ} \mathrm{F}$. They were fed a diet of Purina guinea-pig chow supplemented with hay and fresh cabbage twice weekly and allowed free access to water. Reproductive cycle phases were determined from examination of the vaginal cytology as described by Asdell (1946).

Experiment 1. Inoculation during the follicular and luteal phases of the reproductive cycle

Eight guinea-pigs were placed into two groups, four in the follicular and four in the luteal phase of the reproductive cycle. One animal from each group served as a control. Vaginal cultures were made from each animal to establish the existence of a vibrio-free status. A blunt medicine dropper was used to inoculate the animals intravaginally. Each animal received approximately $1 \times 10^{7}$ viable cells of $V$. fetus in Brucella broth on each of 3 successive days. The control animals were given an equal volume of Brucella broth only. Before the administration of the inoculum on the 2nd and 3rd days, a vaginal culture and smear were taken. Cultures were made for 3 consecutive days after the final inoculation. All the animals were killed 5 days after the final inoculation. The entire reproductive tract was removed aseptically. Cultures were taken from the vagina, proximal and distal cervical areas, both uterine horns and ovaries, the liver, spleen and heart blood. Portions of each tissue were cultured in thioglycollate broth (Difco). Uterine and cervical tissues were preserved in $10 \%$ formalin for subsequent sectioning and staining with haematoxylin and eosin.

\section{Experiment 2. Inoculation during induced and natural oestrus}

Six test and two control animals were used. Their vibrio-free status was confirmed. The control animals were allowed to reach oestrus naturally. The induced oestrous period of the test animals was synchronized with that of the controls by two intramuscular injections of 300 i.u. oestradiol benzoate (Progynon benzoate, Schering Corp., Bloomfield, N.J.) given $72 \mathrm{hr}$ apart. The techniques of inoculation and subsequent examination were identical to those described in Exp. 1. The inoculum given comprised $3 \times 10^{5}$ viable cells per dose to each guinea-pig in the trial. 


\section{Experiment 3. Inoculation of animals treated with progesterone}

The vibrio-free status of six test and two control guinea-pigs was established. Each test animal was given $2.5 \mathrm{mg}$ progesterone (repository type, $25 \mathrm{mg} / \mathrm{ml}$ ) intramuscularly daily for 3 days. After the third injection, inoculation of both test and control animals was started. The size of each dose of inoculum was $3 \times 10^{6}$ viable cells. The study was completed with the methods described in Exp. 1 .

\section{RESULTS}

\section{Experiment 1. Inoculation during follicular and luteal phases}

All animals were vibrio-free before inoculation. None showed any adverse physiological response to the inoculum and remained active and alert throughout the experimental procedures. Anorexia was not noted. The cellular response observed in the vagina of the normally cyclic animals reflected the hormonal state of the reproductive system. Vaginal cytology revealed a slight increase in neutrophils which became more extensive on the 3rd day after

Table 1. Growth of $V$. fetus in vaginal cultures obtained from guinea-pigs during and after intravaginal inoculation

\begin{tabular}{|c|c|c|c|c|c|c|c|}
\hline \multirow{2}{*}{ Phase of cycle } & \multirow{2}{*}{ Animal no. } & \multicolumn{2}{|c|}{ During inoculation* } & \multicolumn{3}{|c|}{ After inoculation } & \multirow{2}{*}{$\begin{array}{c}\text { Necropsy } 5 \text { days } \\
\text { after inoculation } \dagger\end{array}$} \\
\hline & & $24 h r$ & $48 \mathrm{hr}$ & $24 h r$ & $48 h r$ & $72 h r$ & \\
\hline $\begin{array}{l}\text { Test animals } \\
\text { Follicular phase } \\
\text { Luteal phase }\end{array}$ & $\begin{array}{l}1 \\
2 \\
3 \\
4 \\
5 \\
6\end{array}$ & $\begin{array}{l}+ \\
+ \\
+ \\
+ \\
+ \\
+\end{array}$ & $\begin{array}{r}+ \\
+ \\
+ \\
+ \\
+ \\
+\end{array}$ & $\begin{array}{l}+ \\
+ \\
+ \\
+ \\
+ \\
+\end{array}$ & $\begin{array}{l}+ \\
+ \\
+ \\
+ \\
+\end{array}$ & $\begin{array}{l}+ \\
- \\
- \\
+ \\
-\end{array}$ & $\begin{array}{l}- \\
- \\
- \\
- \\
-\end{array}$ \\
\hline $\begin{array}{l}\text { Control animals } \\
\text { Follicular phase } \\
\text { Luteal phase }\end{array}$ & $\begin{array}{l}7 \\
8\end{array}$ & - & - & - & - & - & - \\
\hline
\end{tabular}

+ , Growth of $V$. fetus; - , no growth of $V$. fetus in 5 days at $37^{\circ} \mathrm{C}$.

* Cultures taken 24 and $48 \mathrm{hr}$ after Day 1 of the inoculation period.

$\dagger$ No isolations of $V$. fetus were made from the uterus, cervix, blood, liver or spleen.

inoculation. At necropsy, no gross lesions were observed in the reproductive tract or other visceral organs. Histologically, the uterine tissue of the test animals showed a slight inflammatory reaction with some congestion of the lamina propria. No differences in the gross and microscopic appearances of tissues examined from animals in the luteal or follicular phase of the reproductive cycle could be attributed to the inoculation of $V$. fetus. The results of the bacteriological findings are given in Table 1. Similar patterns of $V$. fetus isolation occurred in both test groups. All animals yielded positive cultures $24 \mathrm{hr}$ after inoculation. After this period, isolations of $V$. fetus from both groups declined, two of three in $48 \mathrm{hr}$ and one of three in $72 \mathrm{hr}$. All tissues cultured at necropsy 5 days after inoculation were free of $V$. fetus. 
Experiment 2. Inoculation during induced and natural oestrus

The animals inoculated during induced and natural oestrus were showing characteristic cornification of the vaginal epithelial cells. Those treated with exogenous oestrogen appeared to tolerate the hormone well. A marked increase in neutrophils was observed in the vaginal cytology. No gross or microscopic lesions were observed at necropsy. The pattern of $V$. fetus isolation is given in Table 2. In animals during both induced and naturally occurring oestrus the infection persisted only throughout the inoculation period, becoming negative within $24 \mathrm{hr}$ after inoculation. Tissues cultured at necropsy were free of $V$. fetus.

Table 2. Growth of $V$. fetus in vaginal cultures obtained from guinea-pigs during and after intravaginal inoculation during oestradiol-induced and natural oestrus

\begin{tabular}{l|c|c|c|c|c|c|c}
\hline & \multirow{2}{*}{ Animal no. } & \multicolumn{2}{|c|}{ During inoculation* } & \multicolumn{3}{|c|}{ After inoculation } & $\begin{array}{c}\text { Necropsy } 5 \text { days } \\
\text { after inoculation } \dagger\end{array}$ \\
\cline { 2 - 7 } & & $24 \mathrm{hr}$ & $48 \mathrm{hr}$ & $24 \mathrm{hr}$ & $48 \mathrm{hr}$ & $72 \mathrm{hr}$ & \\
\hline Test & 1 & + & + & - & - & - & - \\
$\begin{array}{c}\text { (oestradiol- } \\
\text { induced }\end{array}$ & 2 & + & + & - & - & - & - \\
oestrus) & 4 & + & + & - & - & - & - \\
& 5 & + & + & - & - & - & - \\
$\begin{array}{c}\text { Control } \\
\text { (natural } \\
\text { oestrus) }\end{array}$ & 6 & + & + & - & - & - & - \\
\hline
\end{tabular}

+ , Growth of $V$. fetus; -, no growth of $V$ fetus in 5 days at $37^{\circ} \mathrm{C}$.

* Cultures taken 24 and $48 \mathrm{hr}$ after Day 1 of the inoculation period.

$\dagger$ No isolations of $V$. fetus were made from the uterus, cervix, blood, liver or spleen.

Table 3. Growth of $V$. fetus in vaginal cultures obtained from progesterone-treated guinea-pigs during and after intravaginal inoculation

\begin{tabular}{c|c|c|c|c|c|c|c}
\hline & Animal no. & During inoculation* & \multicolumn{3}{|c|}{ After inoculation } & \multicolumn{1}{c}{$\begin{array}{c}\text { Necropsy 5 days } \\
\text { after inoculation } \dagger\end{array}$} \\
\cline { 2 - 6 } & & $24 \mathrm{hr}$ & $48 \mathrm{hr}$ & $24 \mathrm{hr}$ & $48 \mathrm{hr}$ & $72 \mathrm{hr}$ & \\
\hline Test & 1 & + & + & - & - & - & - \\
& 2 & + & + & - & - & - & - \\
& 3 & + & + & + & - & - & - \\
Controgesterone) & 4 & + & + & - & - & - & - \\
(no progesterone) & 5 & + & + & + & - & - & - \\
\hline
\end{tabular}

+ , Growth of $V$. fetus; - , no growth of $V$. fetus in 5 days at $37^{\circ} \mathrm{C}$.

* Cultures taken 24 and $48 \mathrm{hr}$ after Day 1 of the inoculation period.

$\uparrow$ No isolations of $V$. fetus were made from the uterus, cervix, blood, liver or spleen.

Experiment 3. Inoculation of animals treated with progesterone

Following treatment with progesterone, guinea-pigs manifested tenderness and stiffness at the site of injection. A marked eosinophilia was noted in the vaginal cytology of the test animals. This persisted throughout the study. A 
polymorphonuclear response was seen in both test and control animals during the inoculation period. No gross or microscopic lesions were present in either group at necropsy. Vibrio fetus was isolated only during the inoculation period from both test and control animals (Table 3). Two of six test and one of two control animals gave positive cultures $24 \mathrm{hr}$ after inoculation. Tissues cultured from both test and control groups at necropsy were negative for $V$. fetus.

\section{DISGUSSION}

The in-vivo trials described are apparently the first to use a defined isolant of $V$. fetus var. venerealis in the study of guinea-pig infection with the organism generally known as Vibrio fetus. The vaginal route of inoculation was used because it more closely resembles the normal venereal route of infection in cattle, although Ristic \& Morse (1953) reported intravaginal inoculation as the least effective method for the establishment of infection in guinea-pigs. Tables 1 to 3 show a lack of persistence of $V$. fetus in the vagina even when introduced in large numbers. This is in direct contrast with the infection in the heifer in which VanDerplassche, Florent \& Huysman (1957) reported a persistence of at least 8 months' duration.

The bacteriological and histological examinations made after intravaginal inoculation of the guinea-pig gave no indication that the organism entered the uterus. The possibilities of uterine invasion of a duration of less than 5 days was not ruled out in this study. The value of exogenous oestrogen to increase the susceptibility of the guinea-pig to $V$. fetus infection as described by Power (1954) and Adler (1953) was not confirmed in this study. A lack of persistence of the vaginal infection was noted with some indication that the rate of clearance from the vagina was even greater in oestrous animals, regardless of whether oestrus was induced or not. The results of this work support the findings of Ristic \& Morse (1953) and Robinson, van Rensburg, van Heerden \& van Drimmelen (1956) who rejected intravaginal inoculation in favour of intraperitoneal inoculation in guinea-pig studies, especially if the animals were used for diagnostic purposes.

Exogenous progesterone apparently did not increase the susceptibility of the guinea-pig to $V$. fetus infection following intravaginal inoculation. The results of these studies again reflected the lack of persistence described above under other experimental conditions. It is of interest to note that Manclark \& Pickett (1965) were unable to detect the formation of either mucosal or humoral antibodies in the guinea-pig after intravaginal inoculation with live cells of $V$. fetus. Both humoral and mucosal antibodies were found in high titre when live V. fetus cells were inoculated intraperitoneally into mated but non-pregnant guinea-pigs. The failure of the immune response in animals inoculated intravaginally may reflect the apparent lack of antigen persistence demonstrated throughout this work.

Under the experimental conditions used, it is apparent that the female guinea-pig is not a reliable test animal for the diagnosis of $V$. fetus infection in the cow, especially if the intravaginal route of inoculation is used. The cervix apparently forms an effective barrier to the entry of $V$. fetus to the guinea-pig 
uterus and precludes the development of systemic infection. The refractory response of the guinea-pig is considered to be due to the strict host specificity of $V$. fetus var. venerealis which allows for the fullest expression of its virulence solely in the reproductive tract of the cow.

\section{AGKNOWLEDGMENTS}

This work was supported in part by research grant AI-07912 from the National Institute of Allergy and Infectious Diseases, and forms part of a dissertation submitted by the senior author to the Graduate Council of the University of Florida in partial fulfilment of the requirements for the Ph.D. degree.

The technical assistance of Miss Jean Barry in the preparation of tissues for histological examination is acknowledged. The assistance of Dr K. P. C. Nair in interpretation of the tissue sections also is acknowledged.

\section{REFERENGES}

AdLER, H. C. (1953) Diagnosis of Vibrio fetus carrier bulls by intravaginal inoculation of guinea pigs. Nord. VetMed. 5, 454.

Asdell, S. A. (1946) Patterns of Mammalian Reproduction. Comstock Publishing Corporation, Inc., Ithaca, N.Y.

FloRent, A. (1963) A propos des Vibrions responsable de la vibriose génitale des bovins et des ovins. Off. Int. Epiz. 60, 1063.

Lovelt, J. E. (1964) Genital vibriosis in Iowa cattle. Iowa St. U. Vet. 26, 10.

Manclark, R. R. \& Pickett, M. J. (1965) The pattern of the immune response in vibriosis. J. Path. Bact. 90, 627.

Power, J. H. (1954) The intravaginal inoculation of guinea pigs as a method of demonstrating Vibrio fetus in the semen of infected bulls. Ir. vet. 7. 8, 238.

Ristic, M. \& Morse, E. V. (1953) Experimental Vibrio fetus infection in guinea pigs. I. Bacteriological aspects. Am. F. vet. Res. 14, 399.

Robinson, E. M., van Rensburg, S. W. J., van Heerden, J. S. \& van Drimmelen, G. G. (1956) Isolation of Vibrio fetus from bull semen in South Africa. $\mathcal{J l}$ S. Afr. vet. med. Ass. 27, 197.

Sмiтн, T. (1918) Spirilla associated with disease of the fetal membranes in cattle (infectious abortion). 7. $\exp$. Med. 18, 701 .

SмIтн, Т. (1919) The etiological relation of spirilla (Vibrio fetus) to bovine abortion. F. exp. Med. 30, 313.

Smith, T. (1923) Further studies on the etiological significance of Vibrio fetus. F. exp. Med. 37, 341.

VanDerplassche, M. A., Florent, A. \& Huysman, A. (1957) Comite voor sterilitetshestrijding. Verslag over het workjarr. 1956. Diergeneesk. Tijdschr. 26, 52.

WALSH, A. F. \& WHITE, F. H. (1968) Biochemical and serologic characteristics of Vibrio isolants from Florida cattle. Am. F. vet. Res. 29, 1377. 